\title{
Tornar presente Alexandria: metáfora, responsabilidade e julgamento em um texto de imprensa de Eça de Queirós
}

\author{
Breno Góes \\ Pontifícia Universidade Católica do Rio de Janeiro \\ Cátedra Padre Antônio Vieira de Estudos Portugueses \\ Conselho Nacional de Desenvolvimento Científico e Tecnológico
}

\begin{abstract}
Resumo
O presente trabalho tem como objetivo analisar a eficácia de certas escolhas estéticas que Eça de Queirós (1845-1900) faz em seu texto de imprensa "Os ingleses no Egito" (1882), nomeadamente sua opção por uma escrita metafórica. Procura descrever de que forma essas escolhas afastam o texto de um paradigma jornalístico típico, e os impactos de ordem política e moral advindos desse afastamento.
\end{abstract}

Palavras-chave: Eça de Queirós; jornalismo; metáfora; responsabilidade; julgamento.

\begin{abstract}
The present paper aims to analyse the effectiveness of certain aesthetic choices made by Eça de Queirós (1845-1900) in his press text "The English in Egypt" (1882), namely his option in favour of a metaphorical writing. It aims to describe in which way this choices make the text diverge from a typical journalistic paradigm, and the consequential political and moral impacts of that.
\end{abstract}

Keywords: Eça de Queirós; journalism; metaphor; responsibility; judgement.

Recebido em: 27/05/19

Aprovado em: 06/07/19

A imaginação está em declínio. Menos pessoas estão interessadas naquilo que podemos inventar. Na verdade, parece que elas não têm vontade de observar nossas ideias, espantar-se ou inquietar-se diante delas e pensar nos nossos procedimentos. É por isso que acreditam em tudo.

Ricardo Lísias, escritor.

\section{Introdução}

A parte inferior (o rodapé) da primeira página do jornal carioca Gazeta de Notícias, no dia 27 de setembro de 1882, trazia mais uma das Cartas da Inglaterra, seção sob a responsabilidade 
de Eça de Queirós. Este, por sua vez, era então um membro do corpo diplomático português na cidade de Bristol, UK, o que justificava o título da seção. O nome do texto daquele dia era "Os ingleses no Egito", na verdade a primeira de uma série de seis "cartas" assim denominadas.

Um leitor de ocasião, não familiarizado com aquela seção do jornal, talvez tomasse tal texto como uma obra de ficção, não apenas porque o diplomata em questão já era célebre como autor de romances (seu O primo Basílio fora publicado no Rio de Janeiro com grande frisson, em 1878), mas também porque a parte inferior de uma página de qualquer jornal (o feuilleton, palavra que se traduziu do francês para o português como folhetim) já era então frequentemente consagrada às ficções curtas e longas em prosa, que se popularizaram internacionalmente ao longo do século XIX.

Essa suposição de estar diante de uma obra ficcional acentuar-se-ia com a leitura dos primeiros parágrafos do texto: eles consistiam em uma descrição da cidade egípcia de Alexandria através de um registro evidentemente literário, que, ao parodiar o discurso dos "guias de viajantes", fazia recordar imensamente o estilo narrativo do primeiro capítulo do romance $O$ vermelho e o negro, de Stendhal ("Se, ao entrar em Verrières, o viajante perguntar...", etc.) (STENDHAL, 2010, p. 11). Assim começa o texto de Eça:

Até há cinco ou seis semanas Alexandria podia ser descrita no estilo convidativo dos guias de viajantes como uma rica cidade de duzentos e cinquenta mil habitantes, entre europeus e árabes, animada, especuladora, próspera, tornando-se rapidamente uma Marselha do Oriente. Nenhum guia, porém, por mais servilmente lisonjeiro, poderia chamar-lhe interessante.

$[\ldots]$

Cidade feia à vista, desagradável ao olfato, reles, insalubre, Alexandria visitava-se à pressa, ao trote de uma tipóia, e depressa se apagava da memória, apenas o comboio do Cairo deixava a estação, e se ausentavam, entre as primeiras culturas do Delta, ao longo dos canais, as filas de íbis brancos, os mais velhos habitantes do Egipto, outrora deuses, ainda hoje aves sagradas...

$[\ldots]$

Todavia, tal qual era, Alexandria - com a sua baía atulhada de paquetes, de navios mercantes e de navios de guerra; com os seus cais, cheios de fardos e de gritaria, os seus grandes hotéis, as suas bandeiras flutuando sobre os consulados, os seus enormes armazéns, os seus centenares de tipóias descobertas, os seus mil cafés-concertos e os seus mil lupanares; [...] Alexandria realizava o mais completo tipo que o mundo possuía de uma cidade levantina, e não fazia má figura, sob o seu céu azul-ferrete, como a capital comercial do Egipto, e uma Liverpool do Mediterrâneo.

Isso era assim, há cinco ou seis semanas. Hoje, à hora em que escrevo, Alexandria é apenas um imenso montão de ruínas. (QUEIRÓS, 2002, p. 175-176)

Embora não haja qualquer menção a personagens ou tramas ficcionais, toda a descrição de Alexandria apresentada acima é feita através de imagens vivamente traçadas em um tom "literário", que sugerem a iminência de uma intriga romanesca que se passasse nessa cidade 
portuária do Egito: há a alusão a um ponto de vista subjetivo (“Alexandria visitava-se à pressa, ao trote de uma tipóia, e depressa se apagava da memória"); há a aproximação entre um registro concreto (os "íbis brancos") e um simbólico ("deuses"); há o uso de hipérboles ("mil cafésconcertos" e "mil lupanares"); e há, finalmente, uma subversão das expectativas do leitor com a reviravolta súbita e misteriosa sofrida pelo cenário urbano na parte final do trecho citado (que, de "rica cidade", se torna um "imenso montão de ruínas").

Seria preciso um leitor mais assíduo e atento da Gazeta de Notícias para compreender que, apesar de todos esses índices, "Os ingleses no Egito" não era romance algum, nem texto ficcional de qualquer espécie. Apenas esse leitor informado saberia que todas as Cartas de Inglaterra anteriores, apesar de ocuparem sempre a seção de folhetim da Gazeta de Notícias, consistiam invariavelmente em peças não ficcionais de correspondência internacional, em que o diplomata português tecia comentários para o leitor carioca sobre a vida política e social europeia. Esse leitor familiarizado teria ciência de que a cidade de Alexandria de fato fora bombardeada semanas antes: desde o princípio de julho daquele ano a Gazeta de Notícias vinha publicando notícias sobre a invasão do Egito pelas forças armadas britânicas, iniciada exatamente pelo dito bombardeio. Daí a referência ao "montão de ruínas". No dia 13 de julho, o jornal publicara sua primeira nota comentando o fato, ocorrido no dia 11:

O jornal inglês Standard publica as seguintes informações sobre a esquadra inglesa que actualmente se encontra em Alexandria, sob as ordens do Almirante Seymour, e que rompeu já o bombardeio contra aquela cidade.

O Invencivel (450 homens); o Alexandre (666); o Soberbo (620); o Temerário (530); o Monarca (500); o Inflexivel (370); o Rittera (100); o Condor(100); o Helicon (70); o Cygnet (70); o Decoy (60) e a Coquet (60). Este último navio está em substituição do Beacon, que marchou para Port-Said. O número de marítimos ascende a 3.631.

(ASSASSINATOS, 1882, p. 1)

Essa primeira nota, de uma objetividade praticamente telegráfica, é uma peça típica de certa forma mais hegemônica de jornalismo, mas contrasta de forma gritante com as longas e "artísticas" divagações do texto de Eça sobre Alexandria. Ainda assim, veremos que ambos obedecem a uma mesma ideia básica, inclusive comum ao jornalismo como um todo: contar ao leitor um fato ocorrido. O objetivo deste artigo é compreender as especificidades formais da escrita jornalística queirosiana em relação ao paradigma informativo da época, nomeadamente sua escolha por fazer seu leitor imaginar a cidade de Alexandria e os eventos nela sucedidos, e as consequências que podem ser extraídas dessa escolha estética.

\section{O paradigma da informação}

Para que as especificidades da escrita jornalística queirosiana fiquem inteiramente visíveis, é necessário inicialmente contrastá-las com o paradigma da escrita jornalística no 
século XIX (que, diga-se, permanece pouco alterado nos dias de hoje). Tomemos, inicialmente, a própria nota inicial da Gazeta sobre o bombardeio inglês em Alexandria, transcrita acima: ela compõe-se de dois parágrafos. No primeiro deles, o principal fato noticiado (a ocorrência de um bombardeio) aparece apenas em uma oração subordinada, enquanto na oração principal é feita uma referência a certo jornal inglês - o Standard - que serve de fonte à notícia. O segundo parágrafo resume-se a uma lista de nomes e números, indicando os navios e seus tripulantes. Por mais banal que seja esse texto, penso que seja possível ressaltar algo contraditório nos elementos que o compõem. Por um lado, trata-se de uma notícia radicalmente resumida, que nos diz muito pouco a respeito do fato noticiado: a marinha inglesa bombardeou o Egito, mas não sabemos nem sequer os mais simples dados objetivos sobre esse bombardeio (houve mortos? quais foram os prédios atingidos?); sobretudo, não vemos respondidas, ou sequer formuladas, algumas indagações mais especulativas fundamentais que nos permitiriam formar um juízo sobre o evento (o que motivou o bombardeio? ele continuará? o que pensam os envolvidos? qual será o impacto desse evento na política internacional? ele afeta o Brasil?).

Por outro lado, por mais que seja incompleta, a notícia se permite ser extraordinariamente precisa em pontos específicos. Se, como já dissemos, ela não informa o leitor carioca dos "comos e porquês" do bombardeio, ela nos dá detalhes quase pitorescos - como o número exato de tripulantes dos navios ingleses.

Alguém poderá dizer que o problema aqui é o tamanho. A exiguidade do espaço ocupado pela notícia implicaria essa ausência de maiores explicações sobre o evento. Ocorre que não é o caso. Se buscarmos na imprensa inglesa a edição do tradicionalíssimo jornal The Times que aborda o mesmo bombardeio ao porto de Alexandria, vemos que ela é imensamente maior do que a notícia da Gazeta, mas também se resume a listas com detalhes numéricos absurdamente precisos sobre o evento. Continuamos não vendo respondidas aquelas indagações de ordem especulativa, e que no fim poderiam resumir-se em uma só questão: Que se pode pensar do fato de que a Inglaterra bombardeou Alexandria?

Veja-se este trecho da matéria do Times de 12 de julho sobre o ataque, em que um correspondente internacional anônimo relata os eventos do bombardeio com precisão de minutos:

6 AM - As naves estão em posição. Partindo do nordeste em direção ao sudeste, elas estão como indicado a seguir: Alexandra, Sultan, Superb, Inflexible, Téméraire, Penelope, Invincible, e Monarch. canhoneiras estão atrás.

6:20 AM - A Condor recebe um aviso para auxiliar a Teméraire, que alcançou a costa. 7:04 AM - A Alexandra atirou uma bomba no Forte Adda.

7:10 AM — Todas as grandes naves estão atirando, e os fortes estão respondendo. Tiros de ambos os lados parecem ser bastante imprecisos. A mira dos atiradores da Teméraire parece ser a mais precisa. Ela ainda está na costa, assistida pelo Condor. $[\ldots]$ 
11 AM - O Almirante assinala o "cessar-fogo". Nós atiramos um último tiro, e deixamos o Forte Marabout com um único canhão poderoso funcionando.

11:20 AM — Nós passamos abaixo da Inflexible, e a Condor é saudada pela tripulação de sua poderosa consorte. Passando também pela Invincible, cumprimentos são feitos ao nosso capitão, e insultos feitos a Arabi, que os marinheiros apelidaram de "Horrível Paxá" [...] ao longo do porto todos os fortes parecem severamente danificados.

(BOMBARDMENT, 1882, p. 5)

Repare-se, no trecho acima, na preocupação meticulosa com a ordem na qual se dispõem os navios ingleses. O privilégio é da informação precisa e concisa. Menciona-se de passagem que os soldados ingleses insultam um homem chamado Arabi, o que soa como uma mínima alusão a uma polêmica que poderia estar na causa do evento bélico; mas de forma alguma se consegue deduzir daí qualquer interpretação mais robusta sobre o contexto — político, ou de qualquer outra ordem - do bombardeio.

As duas características das notícias aqui mencionadas - o excesso obsessivo de detalhes precisos e a falta de reflexões especulativas sobre um fato - podem ser perfeitamente lidas como facetas de um mesmo fenômeno, descrito por Walter Benjamin em seu ensaio intitulado "O contador de histórias", ${ }^{1}$ dedicado a circunscrever a prática ancestral da narração de histórias e constatar sua decadência: o autor alemão afirma, em certo momento, que o aparecimento da imprensa burguesa fez emergir contra a tradição das histórias orais o paradigma da "informação" (BENJAMIN, 2018, p. 28). Segundo ele, em contraste com os antigos contos tradicionais, a informação típica do texto de imprensa precisa ser verificável e plausível, por isso vem sempre acompanhada de detalhes que possam indiciar seu lastro na realidade. Contudo, é a própria necessidade de verificabilidade que também demanda que a informação seja "compreensível em si e para si" (BENJAMIN, 2018, p. 28.), isto é: precisa. A checagem de uma "informação" depende de que ela não esteja poluída por lacunas, pontas soltas ou ambiguidades que levem à especulação ou à reflexão. Para Benjamin, quaisquer relações de uma "informação" com algo que não seja seu referente específico precisam ser devidamente silenciadas para que ela se constitua enquanto tal.

Ora, se pensamos nos parágrafos de Eça de Queirós citados no início deste trabalho, é nítido e notório que eles estão em total desacordo com o paradigma da informação benjaminiano. Sua notação temporal é imprecisa ("até há cinco ou seis semanas..."), o texto é propositalmente subjetivo, e as imagens literárias utilizadas são - como todas as imagens literárias — bastante dotadas de ambiguidade. A própria escolha por descrever a cidade de Alexandria antes do bombardeio - uma descrição que é importantíssima no texto de Eça, mas ausente das notícias do

\footnotetext{
${ }^{1}$ O ensaio aqui citado é "Der Erzähler. Betrachtungen zum Werk Nikolai Lesskows”, escrito em 1936 por Walter Benjamin. Em sua tradução mais consagrada para o português foi batizado como "O narrador". A tradução aqui referida é a mais recente, de Patrícia Lavelle, publicada em 2018.
} 
Times e da Gazeta — é um índice neste sentido: para uma concepção de jornalismo que entende que o fato objetivo a ser noticiado é um bombardeio, a opção por demorar-se descrevendo casas e ruas que já não existem por terem sido destruídas é, ela própria, uma digressão desnecessária.

\section{Alexandria por metáforas}

Embora a notoriedade de Eça de Queirós como romancista torne tentadora a hipótese de que ele desrespeita o paradigma da informação simplesmente porque "é um artista", essa mesma resposta produz algum desconforto quando se pensa, por exemplo - utilizando os consagrados termos de Roman Jakobson -, na distinção entre textos "referenciais" e "poéticos": enquanto o texto jornalístico seria referencial por excelência, concentrando-se em um objeto extratextual, o uso abundante de metáforas e demais imagens literárias por parte do "artista" Eça de Queirós traria o foco do texto para si próprio (o que o tornaria um texto poético, segundo a definição de Jakobson [1969, p. 118-162]). Isso o tornaria, em tese, pouco eficiente para informar o leitor sobre seu referente. Espero demonstrar que a questão é mais complexa do que isso.

Se a cobertura que o Times dá ao bombardeio encerrava-se "em si e para si", na sua objetividade, a reportagem de Eça parece o oposto, isto é, "aberta" a especulações de diversas naturezas: a saturação de imagens literárias do texto permite que se façam interrogações ao que está sendo lido. O texto já se inicia de maneira ambígua, sobrepondo (ainda no trecho citado na introdução deste trabalho) diversas Alexandrias: o autor primeiro instaura uma imagem da cidade de Alexandria antes do bombardeio, como um lugar que possuía uma série de marcas características e certo modo de vida. Mas vai ainda mais longe: ao falar dos íbis como "as mais velhas aves do Egito", evoca uma outra Alexandria, de um passado mítico, mais remoto. Por fim, apresenta-se uma Alexandria do presente, o "montão de ruínas". Como observou Isabel Pires de Lima, os textos de Eça de Queirós sobre o Oriente procuram “opor e alternar quadros contemporâneos com quadros das civilizações passadas" (LIMA, 1997, p. 85.) Acrescento que essa preocupação de sobreposição é mais do que ornamento retórico: é, em primeiro lugar, o lembrete de que naquele lugar há uma história, e que essa história pode ser invocada para o presente com certa eficácia. Quando dispõe uma série de imagens dessa mesma cidade de forma serial, Eça de Queirós permite que seu leitor estabeleça entre elas tensões comparativas: podemos, em outras palavras, refletir sobre as semelhanças e diferenças entre cada imagem de Alexandria, e este será um recurso importantíssimo perceptível em toda a série "Os ingleses no Egito". Ainda na primeira carta, por exemplo, Eça recupera outras cidades pertencentes a um passado mítico quando cita o Antigo Testamento para dimensionar o bombardeio sobre Alexandria:

Tratando-se do Egito, terra das antigas maldições, pode-se pensar, em presença de tal catástrofe, que passou por ali a cólera de Jeová - uma dessas cóleras de que ainda estremecem as páginas da Bíblia, quando o Deus único, vendo uma cidade cobrir-se da crosta negra do pecado, corria de entre as nuvens a cicatrizá-la pelo fogo como 
uma chaga viva da Terra. Mas desta vez não foi Jeová. Foi simplesmente o almirante inglês Sir Beauchamp Seymour, em nome da Inglaterra e usando com vagar e método por ordens do governo liberal do sr. Gladstone os seus canhões de oitenta toneladas. (QUEIRÓS, 2002, p. 176)

Trata-se do estabelecimento de uma tensão comparativa entre a destruição de Sodoma e Gomorra perpetrada por Jeová, na Bíblia, e a destruição de Alexandria perpetrada pela marinha inglesa - metonimizada na figura do seu almirante. Embora a conclusão do parágrafo seja de que o ato de Sir Beauchamp Seymour não é igual ao de Jeová, ela só é possível porque o texto aponta uma semelhança entre ambos. Pode-se dizer, mesmo, que a relação de semelhança/ diferença estabelecida entre os dois elementos força o leitor a refletir sobre o bombardeio: até certo ponto, o bombardeio é como uma maldição de Jeová. A partir desse ponto, não é mais. Definir esse limite é um trabalho do leitor.

Logo após o trecho citado acima, há outra forma de tensão comparativa, embora não entre tempos distintos. Eça, narrando a escalada de desentendimentos entre a Europa e o Egito que levaria ao bombardeio, descreve o porto de Alexandria e cita a presença de duas esquadras bélicas, uma inglesa e uma francesa, que haviam ancorado ali no início de junho. Trata-se de um evento real, conhecido, também noticiado pelo Times (THE CRISIS, 1882, p. 3). A descrição dessa cena pela pena do português, contudo, embarca por descrições fantasiosas, e culmina com uma descrição das esquadras no porto que por si mesma constitui um juízo acerca do estado das relações internacionais entre Europa e Egito naquele momento, além de sugerir motivações econômicas para o evento. Eça escreve: "as duas bandeiras, da Inglaterra e da França, eram na realidade dois enormes papéis de crédito, içados no alto dos couraçados" (QUEIRÓS, 2002, p. 179.) O recurso a essa metáfora é o que lhe permite fazer um comentário político: sabemos que bandeiras não são de fato papéis de crédito, mas é o fato de Eça instituir essa relação de semelhança que leva o leitor a imaginar a situação de forma a compreender — para além da mera descrição do porto - a usura perpetrada pelos países europeus no país africano. Essa relação de usura é um ponto do referente acessível apenas pelo discurso poético, portanto em flagrante contradição com as ideias de Jakobson.

Aqui, cabe retomarmos brevemente a reflexão de Paul Ricoeur sobre a noção de metáfora, que nos permitirá aclarar essa contradição. O filósofo francês discorda do linguista russo, e compreende a metáfora como algo além de "uma celebração da linguagem por si mesma, às expensas da função referencial” (RICOEUR, 1994, p. 11). Ricoeur insere seu pensamento sobre a metáfora no âmbito mais geral de uma problematização da ideia de "imaginação" tomada como uma mera recuperação mental de imagens sensivelmente apreendidas pela mente em um momento anterior: para ele, ao contrário, o que imaginamos é o produto mesmo da capacidade que a mente tem de inventar novas formas, movimentos e ideias, para além do que foi apreendido pelos sentidos (RICOEUR, 1982, p. 01-10.) A metáfora, dentro desse esquema, 
seria muito mais do que um mero tropo de retórica, tornando-se um caráter atribuível ao texto como um todo (Ricoeur fala de "frase metafórica" e "obra metafórica") capaz de induzir o leitor a realizar algo que ele chama de "trabalho da semelhança" (RICOEUR, 2015, p. 267). Ricoeur define esse "trabalho" como "a ligação entre um momento lógico e um momento sensível" (RICOEUR, 2015, p. 319): diante de uma predicação metafórica (p. ex.: “as bandeiras eram papéis de crédito") temos o trabalho de ordenar os fluxos intuitivos de imagens e referências que possuímos previamente dos termos envolvidos (no caso, "bandeiras" e "papéis de crédito") de modo a encontrar/produzir relações de semelhança entre eles. O produto disso é uma imagem nova, uma compreensão inédita dos termos envolvidos na predicação, interditada ao discurso objetivo (típico da "informação" definida por Benjamin) e acessível apenas pela via metafórica da imaginação.

Dessa forma, na medida em que Eça constrói a narrativa das causas que levaram ao bombardeio de Alexandria, ao mesmo tempo que dispõe uma série de eventos ordenados no tempo - como faria qualquer jornalista - o autor satura cada passo de sua história com descrições vivamente metafóricas dos espaços, eventos e personagens envolvidos, "abrindo-os" para a imaginação reflexiva do leitor.

Vejamos como isso se dá ao longo dos textos que compõem "Os ingleses no Egito". Podemos descrever resumidamente como o texto continua: após falar do porto de Alexandria, Eça narra a revolução nacionalista liderada pelo coronel do exército egípcio Ahmet $\mathrm{Arabi}^{2}$ contra o quediva egípcio Teufique Paxá (um homem alinhado aos interesses europeus) e, já na segunda carta, comenta como essa revolta desequilibrou a balança política entre o Império Otomano e a Europa ocidental. Esse resumo que faço do texto até aqui, contudo, não daria conta de uma série de especulações possíveis sobre essa narrativa, somente acessíveis através do tecido metafórico estabelecido por Eça. A revolução de Arabi, por exemplo, é por ele comparada às revoluções constitucionais europeias do início do século XIX, o que implicitamente coloca em questão a legitimidade com que os países europeus constitucionais se colocam contra ela:

O Kediva declarara-se coacto. Todos que conhecem a história contemporânea de Portugal e de outros curiosos países constitucionais sabem o que significa esta deliciosa frase: "El-rei está coacto!" Isto quer dizer que sua majestade se acha em palácio, cercado de uma populaça carrancuda que agarrou em chuços, arranjou uma bandeira no alto de um pau, e vem impor esta fórmula prodigiosamente desagradável para el-rei: diminuição da autoridade régia e aumento da liberdade pública [...]. (QUEIRÓS, 2002, p. 179)

\footnotetext{
${ }^{2}$ As transliterações mais contemporâneas do nome desse personagem histórico obedecem alternadamente às grafias “Ahmed Urabi” e "Ahmed Orabi”. A opção por manter a forma mais antiga "Ahmet Arabi” justifica-se por ter sido a utilizada no texto de Eça. Cabe ressaltar, ainda, que, durante o processo revolucionário que liderou, Arabi recebeu o título nobiliárquico de paxá. Portanto (também em consonância com o texto de Eça), utilizarei em momentos posteriores deste trabalho a denominação "Arabi-Paxá".
} 
A delicadeza da situação política do Império Turco, por sua vez, é metaforizada como uma comédia teatral, o que torna visíveis as ações contraditórias tomadas por essa potência:

E aqui começa a famosa comédia das vacilações do Sultão:

[...] instado pela Europa a intervir no Egipto, e não querendo que a Europa interviesse, porque isso seria a perda do seu pingue tributo anual, o Sultão decidiu-se a enviar Dervixe-Paxá, uma velha raposa podre de manhas, com a missão de fazer reentrar Arabi no aprisco dos humildes. Mas apenas Dervixe-Paxá começava esta operação, eis que o Sultão inquieto, vendo Arabi e o xerife de Meca de mãos dadas sobre o túmulo do Profeta, remete a Arabi a Grande Ordem do Medjidieh, a mais nobre condecoração turca, o favor supremo que pode cair das mãos do califa, acompanhada de uma florida carta de amizade e duma esplêndida placa de diamantes. (QUEIRÓS, 2002, p. 187)

As tensões comparativas estabelecidas pelas metáforas de Eça, portanto, cumprem a função de tornar necessário o "trabalho da semelhança", forçando uma leitura imaginativa e especulativa dos fatos apresentados. Cabe agora compreendermos quais são as consequências políticas dessa escolha estética. Penso que elas ficam mais claras a partir da terceira carta que compõe "Os ingleses no Egito".

\section{Responsabilidade e julgamento}

Após a segunda carta, preenchida basicamente pelo relato das tensões macropolíticas crescentes no Egito e seu impacto internacional, a terceira carta retorna a Alexandria para narrar o evento que consiste no estopim para o bombardeio inglês: no dia 11 de junho de 1882 , um conflito étnico entre civis europeus e árabes, no bairro europeu de Alexandria, resultou na morte de aproximadamente quatrocentas pessoas, sendo (segundo os dados de Eça) cem cristãos e trezentos árabes. Eça termina a carta com um comentário mordaz sobre a imprensa inglesa (regida, lembremos, pelo paradigma da informação): "Os jornais têm chamado a isso o massacre dos cristãos: eu não quero ser por modo algum desagradável aos meus irmãos em Cristo, mas lembro respeitosamente que isto se chame a matança dos muçulmanos" (QUEIRÓS, 2002, p. 197).

Eça reconhece cinicamente aqui a aparente contradição entre a pretensa objetividade do discurso jornalístico e a opção dos jornais pela nomenclatura imprecisa e injusta de "o massacre dos cristãos". Retornemos, para explicar esse ponto, ao início dessa carta, onde de fato se constrói a oposição entre a versão de Eça e aquela veiculada pela imprensa inglesa. O que é decisivo para que essa oposição se dê é que, logo nas primeiras linhas dessa terceira carta, o autor de $O$ primo Basílio faz uma interessante revelação autobiográfica: ele próprio já estivera em Alexandria no passado. Em 1869, o então jovem recém-formado em direito fora convidado para assistir à inauguração do canal de Suez, evento sobre o qual inclusive veio a escrever quatro reportagens para o Diário de Notícias de Lisboa (QUEIRÓS, 2000, p. 5-21). Suas notas 
privadas sobre essa viagem, que se estenderia ainda até o Cairo e a Palestina, foram depois coligidas por um de seus filhos no volume póstumo $O$ Egito: notas de viagem (QUEIRÓS, 1979). No contexto da reportagem "Os ingleses no Egito", contudo, essas reminiscências estão apenas implícitas nas duas primeiras cartas e, quando são explicitadas na terceira, o são por um motivo específico, e têm uma eficácia específica. As cenas da Alexandria que Eça conheceu em 1869 (mais uma Alexandria do passado a somar-se às outras sobrepostas desde o início da primeira carta) são descritas, então, com a função expressa de ser o outro polo de uma tensão comparativa com a versão da imprensa inglesa sobre o "massacre de cristãos", mais uma vez pondo em marcha o "trabalho da semelhança":

O primeiro episódio oriental que eu vi, ao desembarcar há doze anos em Alexandria, foi este: no cais da alfândega, faiscante sob a luz tórrida, um empregado europeu - europeu pelo tipo, pela sobrecasaca, sobretudo pelo boné agaloado - estava arrancando a pele das costas de um árabe, com aquele chicote de nervo de hipopótamo que lá chamam courbacha, e que é no Egito o símbolo oficial da autoridade.

[...]

Quando no dia 11 de Junho, eu li esses telegramas repassados de pânico, em que se anunciava à Europa que a população árabe massacrava os europeus nas ruas de Alexandria, não sei porquê revi logo o cais da alfândega, o italiano serviçal de boné agaloado, a courbacha estalando nas costas escuras do árabe. (QUEIRÓS, 2002, p. 189-190)

Uma vez mais, estamos diante do processo aclarado por Paul Ricoeur: a tensão entre as duas imagens (a do açoitamento observado no passado versus a do "massacre" noticiado no presente) impõe que façamos especulações sobre as semelhanças e oposições existentes entre elas. Apenas, agora, há o ingrediente até então inédito do jornalista tornado personagem de sua notícia: mais longe do que nunca do paradigma da informação e seus preceitos de objetividade e impessoalidade, o próprio Eça de Queirós coloca seu rastro em Alexandria. Retornando uma vez mais ao ensaio de Benjamin, podemos dizer que é neste momento que Eça põe a nu sua condição de "contador de histórias", obediente à antiga tradição oral que rege essa prática:

Ele [o conto do contador de histórias] não visa transmitir o puro "em si" da coisa como uma informação ou um relatório. Ele mergulha a coisa na vida daquele que a relata para em seguida daí retirá-la. O contador deixa sua marca no conto, assim como o oleiro deixa a impressão de sua mão na argila do vaso. (BENJAMIN, 2018, p. 32)

Inicialmente, parece possível imaginar que a opção de Eça por explicitar seu laço biográfico com a cidade estaria ligada a uma espécie de argumento de autoridade: "deixar a impressão de sua mão", neste caso, equivaleria a dizer que seu discurso a respeito de Alexandria e dos eventos que lá aconteceram seria validado por seu conhecimento da região. O correr da carta, no entanto, coloca um problema mais complexo. Ao longo do texto, Eça vai desenvolvendo a ideia de que o 
descontentamento dos fellah (os proletários egípcios, de religião islâmica) para com os europeus - que em última análise é causa fundamental da revolução de Arabi Paxá e do embate no bairro europeu - decorreu de décadas de abusos perpetrados por empresários e aventureiros europeus na cidade de Alexandria, em conluio com o quediva. Nesse ponto, o escritor português uma vez mais se lembra de sua viagem para a abertura do canal de Suez, agora salientando que as suntuosas comemorações da inauguração desse canal - construído, aliás, com a mão de obra barata do fellah - teriam ajudado a endividar o Egito com a Inglaterra, fornecendo mais argumentos para a invasão. Nesse ponto, Eça responsabiliza-se pela desgraça Egípcia. Vale-se de sua condição biográfica de ex-visitante do local para implicar-se (implicando consigo a sua comunidade de leitores, como veremos, ao usar a primeira pessoa do plural) na situação política de lá:

Quem não se lembra das festas do Canal de Suez? Aí cada verba se contou por milhões. Dois milhões para a iluminação do Cairo. Quatro Milhões para o banquete de Ismailia. [...] Para o champanhe bebido nessas semanas de bambocha — dois milhões! O fellah pagava.

Eh! E eu que estou aqui a falar — também o bebi, esse champanhe que era no fundo o suor do fellah espumante e açucarado. Também eu fui hóspede de Ismail-Paxá, à custa do fellah! Também eu... Calêmo-nos, cubramos a fronte de cinzas implorando o perdão do fellah! (QUEIRÓS, 2002, p. 196)

Evidentemente, não se trata, aqui, de admissão de culpa ou responsabilidade pessoal. Esta é sempre intransferível e individual: as falácias de que "todos europeus são culpados pelas práticas imperialistas de seu continente", por exemplo, ou de que "toda a humanidade é culpada por cada um de seus crimes" não fazem mais que mitigar a responsabilidade dos indivíduos que de fato agiram para a perpetração de tais práticas e portanto constituem em um mero ato de solidariedade para com criminosos. A noção que Eça parece estar construindo aqui, mais refinada, é a de uma responsabilidade coletiva: seu gesto de implicar-se na história que conta parece ser o de reconhecer a existência de uma comunidade (pode-se falar aqui dos europeus, ou dos ocidentais) que liga seus membros de forma vicária a atos cometidos por algum outro membro. A cientista política Hannah Arendt discorreu longamente sobre essa questão em seus últimos anos de vida, e sua produção neste período tem sido de grande valia nesta pesquisa. Em um texto intitulado exatamente "Responsabilidade coletiva", ela escreve:

[...] diria que duas condições têm de estar presentes para a responsabilidade coletiva: devo ser considerado responsável por algo que não fiz, e a razão para a minha responsabilidade deve ser o fato de eu pertencer a um grupo (um coletivo), o que nenhum ato voluntário meu pode dissolver [...] Esse tipo de responsabilidade, na minha opinião, é sempre política, quer apareça na forma mais antiga em que toda uma comunidade assume a responsabilidade por qualquer ato de seus membros, quer no caso de uma comunidade ser responsável pelo que foi feito em seu nome. (ARENDT, 2004, p. 216) 
Não por acaso, Arendt usa para suas conclusões sobre a responsabilidade coletiva o mesmo apoio teórico que Paul Ricoeur utilizaria anos depois para desenvolver sua teoria da metáfora: refiro-me à Crítica da faculdade de julgar, de Immanuel Kant. É de Kant que Ricoeur retirará seu conceito de imaginação, e seu conceito de metáfora é diretamente tributário da noção de "conhecimento simbólico" do filósofo prussiano (LAVELLE, 2018). Da mesma maneira, Hannah Arendt funda sua noção de responsabilidade coletiva na "capacidade de julgar" kantiana, que por sua vez enraíza-se (nos casos específicos que interessam a ela) em uma noção muito específica de "senso comum".

Para Kant, que compreendeu em suas duas primeiras Críticas os conceitos de "Verdadeiro" (em relação ao conhecimento) e "Certo" (em relação à moral) como atrelados a padrões fixos e regras gerais intrínsecas ao homem, o mau juízo em relação ao conhecimento ou à moral só poderia se dar no caso da estupidez ou insensatez daquele que julga. Contudo, no caso específico do juízo de gosto (estético), Kant compreendeu que não havia tais padrões fixos (KANT, 2016), portanto foi obrigado a considerar os juízos estéticos não mais sob a ótica de um modelo de homem ideal, mas considerando "os homens no plural, vivendo em comunidade" (ARENDT, 2004, p. 208). Hannah Arendt, escrevendo após os horrores totalitários da primeira metade do século XX, estende essa ausência de padrões fixos para o campo da moralidade, transportando assim as reflexões estéticas de Kant para essa seara. É neste contexto que a noção de "senso comum" importa como aquilo que nos torna capazes de viver em comunidade e comunicar mutuamente experiências. O senso comum consistiria em uma "capacidade imaginativa" (ARENDT, 2004, p. 205), de (em acordo com o conceito de imaginação apresentado anteriormente) inventar na mente fatos, pessoas e experiências ausentes. Tal capacidade de presentificar o ausente capacitaria qualquer um, no ato de julgar, a levar em conta imaginativamente os juízos dos demais sobre um mesmo objeto ou fato. É a capacidade de presentificar o ausente através da invenção imaginativa, no ato de julgar, que interessa à Arendt: "O aspecto importante da questão é que meu julgamento de um caso particular não depende meramente de minha percepção, mas de eu representar para mim mesmo algo que eu não percebo" (ARENDT, 2004, p. 206).

É, portanto, no ato de julgar que se começa a fundar uma comunidade entre aquele que julga e os demais que são considerados em seu julgamento. Essa fundação só se conclui, no entanto, quando o juízo em questão é comunicado e debatido. O julgamento gera debate, o debate funda a comunidade, a comunidade implica responsabilidades coletivas para seus membros. A questão que Arendt deixa em aberto (tendo falecido justamente no processo de escrita do capítulo intitulado "Julgamento" de seu último livro) é a da condição de comunicabilidade desses juízos que, embora considerando imaginativamente os outros, continuam sendo realizados por indivíduos sem ter qualquer parâmetro fixo como guia. No caso específico dos juízos morais, a questão torna-se extremamente grave para Arendt, dado que ela compreende que agir sem julgar considerando os demais, como se houvesse 
parâmetros fixos no âmbito moral a serem obedecidos cegamente, seria exatamente incidir na chamada "banalidade do mal" (ARENDT, 2004, p. 212).

A reflexão de Paul Ricoeur sobre a metáfora é a resposta teórica para o impasse deixado por Arendt, e o texto "Os ingleses no Egito", de Eça, parece ser uma demonstração "prática" dessa resposta. Devido a seu caráter metafórico, a reportagem em questão tem o poder de comunicar indiretamente ao leitor o juízo específico que seu autor faz de certo evento, mas de uma maneira tal que o leitor é ele mesmo instigado a formular seus próprios juízos quando realiza o "trabalho da semelhança", integrando-se assim a uma comunidade de debatedores. Parece ser essa potência essencialmente política do texto de Eça que outros textos jornalísticos perdem ao recusarem a via indireta e imaginativa da metáfora em favor da pretensa objetividade do paradigma da informação.

\section{Conclusão: de Alexandria para o mundo}

As matérias dos jornais ingleses a respeito da invasão do Egito foram fundamentais para que a opinião pública britânica apoiasse irrestritamente a guerra que supostamente libertaria os egípcios do "horrível Paxá", mas que sabemos hoje ter consistido no passo inicial da longa ocupação imperialista daquele país pela Inglaterra, encerrada apenas na década de 1950. Já vimos que esse apoio não foi construído a partir de matérias panfletárias ou sensacionalistas a favor da invasão, mas meramente com reportagens que - por serem obedientes ao paradigma da informação - eram refratárias ao julgamento, à especulação e em última análise ao senso de responsabilidade de cada leitor. Pode-se falar aqui, citando de forma descontextualizada o trecho do escritor Ricardo Lísias utilizado como epígrafe deste trabalho, de um "declínio da imaginação" (LÍSIAS, 2018, s. p.) ocorrido na Inglaterra de então.

Já vimos, ainda, que a série de textos de Eça opera em sentido contrário, como um excitante da imaginação, buscando a todo momento metáforas e imagens que tensionam os fatos que pertencem à história contada. Vimos o impacto político dessa escolha estética no que diz respeito ao estímulo a julgamentos sobre o que é lido, e a consequente responsabilização do leitor.

Resta ainda comentar um movimento de decisiva importância no final do texto de Eça, que inverte a relação entre o bombardeio de Alexandria e as metáforas. Se antes estas vinham lançar luz sobre o evento bélico, agora é ele que se torna metáfora, para estimular uma reflexão mais ampla sobre os rumos do mundo. Eça demanda de seu leitor um "trabalho da semelhança" para que se estabeleçam conexões entre as imagens de Alexandria bombardeada e outros eventos políticos do mundo, alguns já ocorridos, outros meramente possíveis. Eça transforma os eventos que acabara de noticiar, enfim, em uma imagem do imperialismo: em primeiro lugar, num trecho que se tornou famoso por parecer uma profecia da Primeira Guerra Mundial, Eça zomba das fracas justificativas inglesas para invadir o Egito, e imagina um futuro 
próximo em que todas as potências europeias passassem a invadir países menores a seu belprazer (QUEIRÓS, 2002, p. 209). Em segundo lugar, reflete sobre como a ocupação inglesa no Egito aumenta ainda mais o império britânico, contribuindo assim para tornar o mundo mais homogêneo, sem nuances ou variações (QUEIRÓS, 2002, p. 213).

Eça, esse nativo de Póvoa do Varzim que vive em Bristol, parte de um bombardeio em Alexandria para refletir sobre os rumos do planeta no rodapé de um jornal do Rio de Janeiro. Cabe aqui pensarmos sobre o cosmopolitismo desse gesto. Walter Benjamin, ao descrever o paradigma da informação, além de elencar as características que explorei neste trabalho, cita seu caráter pragmático: um texto de jornal deveria, em tese, fornecer informações que interessassem diretamente seu leitor, elegendo temas próximos a ele. Benjamin cita que um leitor de jornal considera mais importante um incêndio ocorrido num sótão de sua comunidade do que uma revolução em uma cidade distante (BENJAMIN, 2018, p. 28). Eça, como vimos, escolheu escrever sobre a revolução na cidade distante. A chave para explicar mais essa distância tomada pelo português em relação ao paradigma jornalístico é a ideia de comunidade. Hannah Arendt, ao analisar o conceito de "senso comum" de Kant, que já pude expor anteriormente, cita que um homem dotado de senso comum

reivindica a aprovação dos outros porque no ato de julgar já os levou em consideração e, por isso, espera que seus julgamentos venham conter uma certa validade geral, ainda que talvez não universal. A validade vai se estender a toda comunidade da qual meu senso comum me torna membro - Kant, que se julgava um cidadão do mundo, esperava que se estendesse à comunidade de toda a humanidade. (ARENDT, 2004, p. 206)

A pretensão de Eça de Queirós não me parece tão distante da de Kant. Também o autor de $A$ relíquia quer, pelo menos nessa altura de sua vida, ser um cidadão do mundo. Mas não em um sentido iluminista, que tem a pretensão de que seus valores hegemônicos correspondam a certa ideia de razão universal. O texto "Os ingleses no Egito", que repudia o imperialismo europeu e procura compreender o ponto de vista de um grupo periférico na lógica do progresso (os fellah do Egito), parece antes o oposto disso: a reportagem aqui em causa tende a reforçar a interessante hipótese de Helena Buescu, de que Eça de Queirós é capaz de praticar certa “antropologia literária" (BUESCU, 2001, p. 128), produzindo um discurso que estranha o seu próximo (a Inglaterra) e sente-se próximo de quem lhe é distante (os fellah egípcios). Também Giuliano Ito, escrevendo especificamente sobre "Os ingleses no Egito", parece reconhecer algo da mesma ordem: "Não digo que Eça se coloque no lugar dele [do fellah egípcio], mas, ao menos, apresenta empatia. Poderíamos dizer que se a relação entre europeus e egípcios figurava como um 'eu' e um 'outro', no texto de Eça busca-se um 'nós'” (ITO, 2018, p. 54).

Trata-se de compreender-se cidadão do mundo por se sentir à altura do monumental esforço de imaginação que é tornar presentes na mente e no papel os mais distintos pontos 
de vista sobre esse mundo, as mais diversas formas de experimentá-lo, levando em conta os mais diversos povos e circunstâncias. Trata-se de ser cidadão do mundo, enfim, por julgar-se corresponsável por seus rumos.

\section{Referências}

ARENDT, Hannah. Responsabilidade e julgamento. São Paulo: Companhia das Letras, 2004. ASSASSINATOS em Alexandria. Gazeta de Notícias, Rio de Janeiro, p. 1, 13 jul. 1882.

BENJAMIN, Walter. O contador de histórias. In: . A arte de contar histórias. Tradução: Patrícia Lavelle. São Paulo: Hedra, 2018. p. 19-58.

BOMBARDMENT of the forts at Alexandria. The Times, London, p. 5, jul.12 1882.

BUESCU, Helena Carvalhão. Chiaroscuro: modernidade e literatura. Porto: Campo das Letras, 2001.

ITO, Giuliano. O Egito sob o domínio europeu: um olhar queirosiano. In: MARGATO, Izabel et. al. (orgs.). Realismo, realismos: objetos, escritas, efeitos. Rio de Janeiro: 7Letras, 2018.

JAKOBSON, Roman. Linguística e poética. In: . Linguística e comunicação. Tradução: Izidoro Blikstein e José Paulo Paes. São Paulo: Cultrix, 1969.

KANT, Immanuel. Crítica da faculdade de julgar. São Paulo: Vozes, 2016.

LAVELLE, Patrícia. Literatura, reflexão e semelhança: uma afinidade entre Benjamin e Ricoeur. Kriterion, Belo Horizonte, n. 139, p. 235-253, abr. 2018.

LIMA, Isabel Pires de. Os Orientes de Eça de Queirós. Semear, Rio de Janeiro, n. 1, p. 81-95, jan 1997.

LÍSIAS, Ricardo. Diário da catástrofe brasileira I: transição (3. ${ }^{a}$ versão). Amazon,2018. E-book. QUEIRÓS, Eça de. “O Egito”. In: Obras de Eça de Queiroz. Porto: Lello \& IrmãoEditores, 1979. v. III.

. De Port Said a Suez. In: . Notas contemporâneas. Lisboa: Livros do Brasil, 2000. . Textos de imprensa IV (da Gazeta de Notícias). Lisboa: Imprensa Nacional-Casa da Moeda, 2002.

RICOEUR, Paul. Imaginação e metáfora. Psychologie Médicale, Paris, n. 14, p. 1-10, avr. 1982. Disponível em:

http://www.uc.pt/fluc/lif/publicacoes/textos_disponiveis_online/pdf/imaginacao_e_metafora. Acesso em: 4 set. 2018. Prefácio. In: . Tempo e narrativa. São Paulo: Papirus, 1994. . A metáfora viva. São Paulo: Loyola, 2015.

STENDHAL. O vermelho e o negro. São Paulo: Cosac Naify, 2010.

THE CRISIS in Egypt. The Times, London, p. 3, may 171882. 


\section{Minicurrículo}

Breno Góes é doutorando pela Pontifícia Universidade Católica do Rio de Janeiro, orientado pela professora Izabel Margato. Concluiu seu mestrado e graduação na mesma instituição. Pesquisador vinculado à Cátedra Padre Antônio Vieira de Estudos Portugueses e ao Conselho Nacional de Desenvolvimento Científico e Tecnológico. Investiga relações estético-políticas na obra de Eça de Queirós. 